\title{
Characteristics of diazotrophs in surface to abyssopelagic waters of the Sargasso Sea
}

\author{
Ian Hewson ${ }^{1, *}$, Pia H. Moisander ${ }^{1}$, Katherine M. Achilles ${ }^{1}$, Craig A. Carlson ${ }^{2}$, \\ Bethany D. Jenkins ${ }^{3}$, Elizabeth A. Mondragon ${ }^{1}$, Amanda E. Morrison ${ }^{1}$, \\ Jonathan P. Zehr ${ }^{1}$ \\ ${ }^{1}$ Department of Ocean Sciences, University of California Santa Cruz, 1156 High Street EMS D446, Santa Cruz, \\ California 95064, USA \\ ${ }^{2}$ Department of Ecology, Evolution and Marine Biology, University of California Santa Barbara, Santa Barbara, \\ California 93106, USA \\ ${ }^{3}$ Department of Cell and Molecular Biology and Graduate School of Oceanography, University of Rhode Island, \\ 316 Morrill Hall, 45 Lower College Road, Kingston, Rhode Island 02881, USA
}

\begin{abstract}
The presence and expression of nitrogenase genes in diazotrophic prokaryotes has been documented in oligotrophic surface waters of the North Pacific gyre; however, there have been few investigations in other ocean basins. We initiated a study into the ecology of planktonic diazotrophs at 4 stations in the Sargasso Sea. Nucleic acid samples from the surface to $5890 \mathrm{~m}$ were collected on several dates between October 2003 and September 2005. Surprisingly, nifH could only be amplified from nano- and picoplankton DNA in surface waters on only 1 of 2 sampling dates at 1 station in the Sargasso Sea. Although no nifH was detected in the surface DNA samples earlier in the year at that station, Crocosphaera sp. cyanobacterial nifH was detected in enrichment cultures initiated with surface water collected at the time. In contrast to surface waters, diazotrophs were more consistently detected in deeper waters, including at several stations elsewhere globally. The nifH microarray fingerprints from the Sargasso Sea from 0, 5 and $25 \mathrm{~m}$ depths were remarkably consistent between samples taken 2 yr apart, but were different from fingerprints from subeuphotic waters. The results of our study suggest the presence of diazotrophic plankton in the Sargasso Sea, which is not constrained to surface waters. Furthermore, our study demonstrates that a deep-water diazotrophic flora persists in the meso- and abyssopelagic zones in the presence of high concentrations of combined nitrogen; however, the gene expression patterns of such species and their role in the $\mathrm{N}$ cycle remain unknown.
\end{abstract}

KEY WORDS: Diazotroph $\cdot$ Mesopelagic $\cdot$ Microarray $\cdot$ Nitrogenase $\cdot$ Bermuda Resale or republication not permitted without written consent of the publisher

\section{INTRODUCTION}

Marine nitrogen fixation is a globally important process, delivering at least $80 \mathrm{Tg} \mathrm{N} \mathrm{yr}^{-1}$ into surface waters of the ocean (Capone et al. 1997), supporting the $\mathrm{N}$ demand of primary producers (Carpenter \& Romans 1991) and, ultimately, of higher trophic level food webs (Montoya et al. 2002). Marine diazotrophs comprise a diverse suite of unicellular and colonial prokaryotes; these have been detected by measure- ments of nitrogen fixation activity (Capone 1993) or by molecular approaches that detect the presence and expression of the genes that encode the enzyme that catalyzes nitrogen fixation (Zani et al. 2000, Zehr et al. 2001).

Nitrogen fixation is catalyzed by the enzyme nitrogenase, which has been targeted for assemblage-level analyses to determine the distribution of nitrogen fixers in open ocean waters (Zehr \& McReynolds 1989, Zehr et al. 1998). While nitrogen fixation has been tra- 
ditionally ascribed to large colonial or symbiotic cyanobacteria (i.e. Trichodesmium and the diatom endosymbiont Richelia sp.) in oligotrophic tropical and subtropical ocean waters (Capone et al. 1997, Carpenter et al. 1999), recent studies using a gene-based approach have elucidated a wider suite of diazotrophic microorganisms, including unicellular cyanobacteria and heterotrophic bacteria (Zehr et al. 1998, 2000, 2001, Falcon et al. 2002, 2004, Short et al. 2004, Church et al. 2005a,b) and endosymbionts within flagellated eukaryotes (Foster et al. 2006) and within metazoan organisms (Proctor 1997, Braun et al. 1999). These studies suggest that diazotrophs and their associated nitrogen fixation activity may be more widely dispersed than previously believed based upon geochemical rate measurements, extending to habitats in which the larger cyanobacterial diazotrophs are rarely observed.

The abundance of diazotrophs and nifH gene expression have been studied primarily within the North Pacific gyre, at the Hawaii Ocean time-series station ALOHA (Zehr et al. 2001, Falcon et al. 2004, Montoya et al. 2004, Church et al. 2005a,b) in epipelagic euphotic $(<150 \mathrm{~m})$ waters. Initial discovery of nifH gene transcripts at this location (Zehr et al. 2001) prompted development of phylotype-specific quantitative PCR probes, which have been used in a wider suite of environments, including an estuary (the Chesapeake Bay) (Short et al. 2004). While other community-level studies have been conducted within the offshore Amazon River Plume and adjacent equatorial Atlantic Ocean (Falcon et al. 2002) and in the Arabian Sea (Bird et al. 2005), there remain remarkably few studies of non-colonial diazotrophs at oceanic locations typical of open ocean gyres. A recent study of nifH sequences in the vicinity of hydrothermal vents of the Juan de Fuca ridge indicated that diazotrophs may persist in deep ocean waters (Mehta et al. 2003), extending the range of environments in which diazotrophs were believed to occur into regions with presumably high combined nitrogen concentrations.

The Bermuda Atlantic time series (BATS) station and nearby Hydrostation $S$ have been the focus of intense oceanographic research in the past 2 decades (Fasham et al. 2001) and are presumed to be representative of open ocean gyres. These stations are characterized by ultra-oligotrophic conditions during summer months, with convective overturn during late summer and spring (Steinberg et al. 2001) and the occurrence of ephemeral mesoscale eddies which originate from the Gulf Stream (Sweeney et al. 2003, Westberry \& Siegel 2003). The ultra-oligotrophic conditions that prevail seasonally should support the activities of diazotrophic organisms, since nitrogen fixation should provide an ecological advantage for growth in nutrient-depleted waters. A study of bacterioplankton community dynamics has indicated strong links between the relative abundance of bacterial phylotypes and the convectional overturn (Morris et al. 2005), suggesting tight coupling between organic and inorganic nutrient availability and the response of microbial assemblages. Trichodesmium has historically been reported to occur in waters in the vicinity of Bermuda (e.g. during the Challenger expedition) (Capone et al. 1997), and recent studies have documented the seasonality of their nitrogen fixation (Orcutt et al. 2001). To date, there have been no reports on the non-colonial diazotroph population dynamics near Bermuda. Nitrogenase genes were not detected in a recent metagenomic study of waters near Bermuda (Venter et al. 2004), albeit the abundance detection limit for such studies is relatively high (ca. $0.3 \%$ of cell abundance, or ca. $3 \times$ $10^{3}$ cells $\mathrm{ml}^{-1}$ ) and samples were pre-filtered (Johnston et al. 2005). In contrast, a recent study of nifH diversity primarily at latitudes $<18^{\circ} \mathrm{N}$ indicated the presence of unicellular cyanobacterial phylotypes (termed the Group A unicellular cyanobacterial phylotype, Zehr et al. 2001) dominating at stations $>10^{\circ} \mathrm{N}$ (Langlois et al. 2005). That study also reported diazotrophs at latitudes of 20 to $30^{\circ} \mathrm{N}$ in the eastern North Atlantic Ocean (Langlois et al. 2005).

The aim of the present study was to examine diazotroph assemblages in surface to abyssopelagic waters near Bermuda and compare these assemblages to other locations in the North Atlantic and Pacific Oceans. The study was conducted on samples collected in summer and autumn, and at depths from the surface to $5948 \mathrm{~m}$. We used both enrichment culture and culture-independent (i.e. molecular) approaches to determine the phylogenetic affinity of nitrogenfixing prokaryotes in these samples and to compare the composition of these assemblages to those occurring at other locations within the North Atlantic gyre. Additionally, we obtained meso- to bathypelagic samples from elsewhere in the North Atlantic and North Pacific Oceans for comparison to Sargasso Sea mesoto abyssopelagic samples.

\section{MATERIALS AND METHODS}

Sampling regime. Samples for diazotroph analysis were collected at 3 stations in the Sargasso Sea (A22.36, A22.54 and Bermuda Atlantic time series [BATS]) during 2 hydrography cruises aboard the RV 'Knorr' in October and November 2003. Samples were also collected at Hydrostation S in June 2005 (HS6-05) and September 2005 (HS9-05) on the RV 'Weatherbird II' (Fig. 1, Table 1). On all cruises, seawater was collected using Niskin bottles mounted on a CTD rosette. 


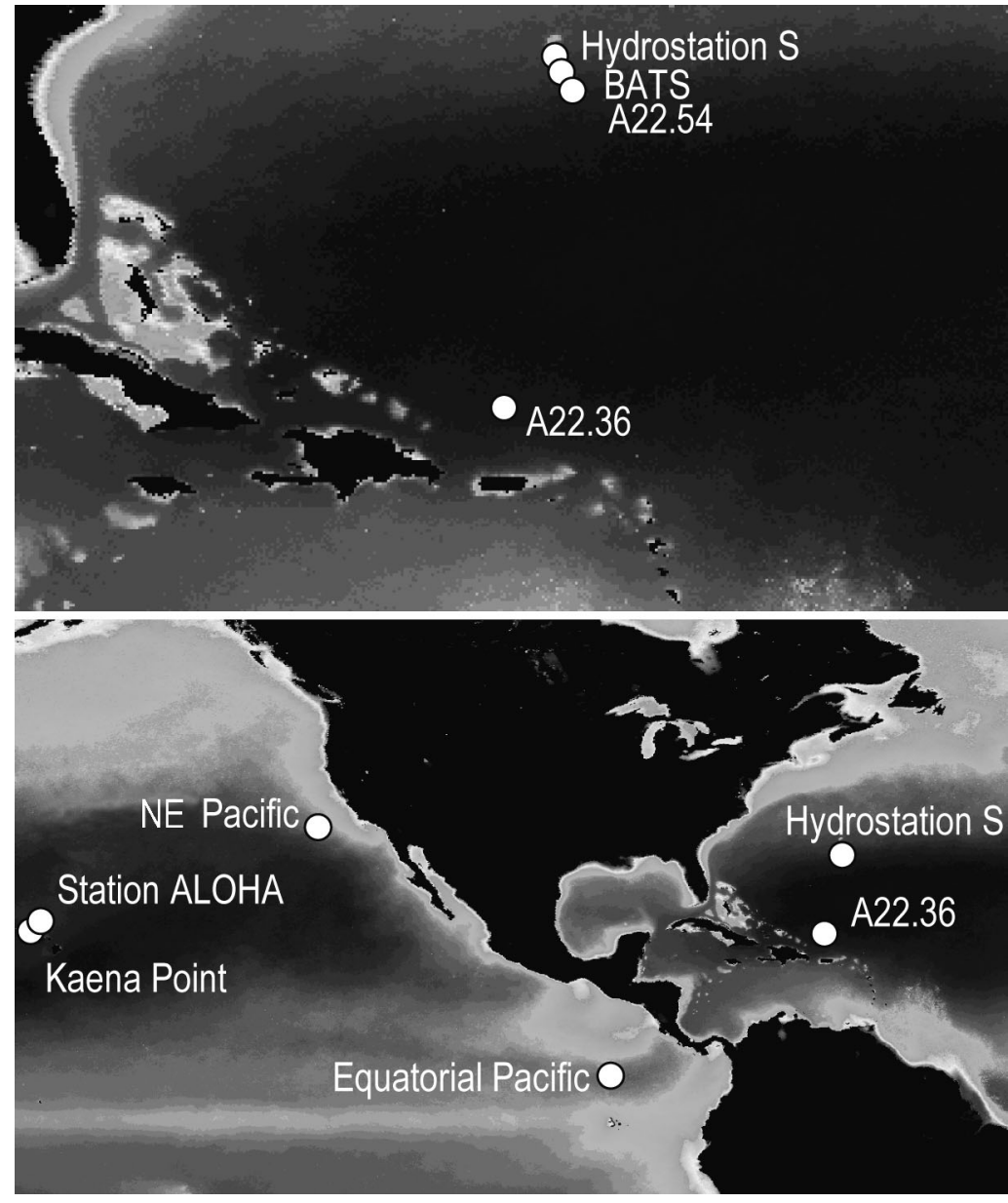

Fig. 1. Surface sampling locations in the North Atlantic Ocean (A) and meso- to abyssopelagic depths in the Atlantic and Pacific Oceans (B). The background image is a map of $2 \mathrm{yr}$ mean satellite-derived (SeaWiFS) chlorophyll $a$, where lighter hues indicate more productive regimes than darker hues

water samples were obtained from the BATS station in November 2003. Samples were collected in October 2003 at Stn A22.36 $(0,25,75,125,275,575$, 950, 3125, 4875, 5600 and $5948 \mathrm{~m}$ depths) and at Stn A22.54 (0, 40, 100, 140, 250, 505 and $1010 \mathrm{~m}$ depths). Upon shipboard retrieval, seawater was drained immediately into 21 acidwashed and seawater-rinsed polycarbonate bottles, which were capped and processed immediately for DNA extraction (described below). Data obtained using the CTD included in vivo fluorescence, salinity, temperature, beam transmissometry and dissolved oxygen. Samples were also taken in the meso- to abyssopelagic zone at 4 other locations in the North Atlantic and North Pacific Oceans between July and November 2005 for comparison to the Sargasso Sea deep water assemblages (Table 1).

Enrichment culture preparation. Triplicate seawater samples from $10 \mathrm{~m}$ at HS6-05 were collected in 21 acidwashed and seawater-rinsed polycarbonate bottles. Immediately the samples were serially filtered through $25 \mathrm{~mm}$ diameter, $10 \mu \mathrm{m}$ pore-size polyester (Poretics), $1 \mu \mathrm{m}$ pore-size Nuclepore PC (Whatman) and $0.2 \mu \mathrm{m}$ poresize Supor (Pall Gelman) filters using a positive-pressure manifold driven by peristaltic-pump on low setting. The filters from each replicate were then immediately placed separately into

At HS6-05, DNA samples were taken from 2 casts (1 at 12:00 $\mathrm{h}$ and 1 at 15:30 h), from 8 depths $(5,30,60,80$, $95,110,140,160 \mathrm{~m})$. At HS9-05, DNA samples were collected from the surface and $200 \mathrm{~m}$. Surface and $25 \mathrm{~m}$
$35 \mathrm{ml} \mathrm{SN} \mathrm{(3} \mathrm{samples)} \mathrm{(Waterbury} \mathrm{et} \mathrm{al.} \mathrm{1986)} \mathrm{or} \mathrm{SO} \mathrm{(SN}$ media without $\mathrm{NO}_{3}{ }^{-}$addition; 3 samples) media in $60 \mathrm{ml}$ acid-washed, autoclaved and seawater-rinsed culture vessels. Enrichment cultures were incubated in

Table 1. Sampling locations and dates from stations worldwide

\begin{tabular}{|c|c|c|c|c|c|}
\hline Location & Latitude & Longitude & Date & Depth (m) & No. of samples \\
\hline BATS & $31^{\circ} 40^{\prime} \mathrm{N}$ & $64^{\circ} 10^{\prime} \mathrm{W}$ & 1 Nov 03 & $0-25$ & 2 \\
\hline HS6-05 & $32^{\circ} 10^{\prime} \mathrm{N}$ & $64^{\circ} 30^{\prime} \mathrm{W}$ & 25 Jun 05 & $0-1000$ & 8 \\
\hline HS9-05 & $32^{\circ} 10^{\prime} \mathrm{N}$ & $64^{\circ} 30^{\prime} \mathrm{W}$ & 20 Sep 05 & $5-2000$ & 3 \\
\hline A22.36 & $20^{\circ} 26^{\prime} \mathrm{N}$ & $66^{\circ} 00^{\prime} \mathrm{W}$ & 31 Oct 03 & $0-5948$ & 10 \\
\hline A22.54 & $31^{\circ} 38^{\prime} \mathrm{N}$ & $64^{\circ} 10^{\prime} \mathrm{W}$ & 6 Nov 03 & $0-1010$ & 7 \\
\hline Costa Rica upwelling dome & $10^{\circ} 00^{\prime} \mathrm{N}$ & $96^{\circ} 30^{\prime} \mathrm{W}$ & 27 Jul 05 & 1381 & 1 \\
\hline NE Pacific & $34^{\circ} 00^{\prime} \mathrm{N}$ & $129^{\circ} 00^{\prime} \mathrm{W}$ & 22 Oct 05 & $125-1500$ & 6 \\
\hline Kaena Point & $21^{\circ} 51^{\prime} \mathrm{N}$ & $158^{\circ} 22^{\prime} \mathrm{W}$ & 13 Nov 05 & $500-3000$ & 3 \\
\hline Stn ALOHA & $22^{\circ} 45^{\prime} \mathrm{N}$ & $158^{\circ} 00^{\prime} \mathrm{W}$ & 13 Nov 05 & $500-3000$ & 4 \\
\hline
\end{tabular}


the shade on board the research vessel for $2 \mathrm{~d}$ prior to transport to the laboratory at the University of California Santa Cruz, where they were placed in a $25^{\circ} \mathrm{C}$ incubator with fluorescent lights (ca. 50 $\mu \mathrm{mol}$ quanta $\mathrm{m}^{-2} \mathrm{~s}^{-1}$ ) with a $12 \mathrm{~h}$ light:dark cycle. After $14 \mathrm{~d}$ incubation, $5 \mathrm{ml}$ from each culture was filtered through $0.2 \mu \mathrm{m}$ pore-size Nuclepore filters ( $25 \mathrm{~mm}$; Whatman) and placed immediately into a sterile Petri dish and frozen at $-80^{\circ} \mathrm{C}$ until further processing for DNA analysis. Additionally, small aliquots (100 $\mu \mathrm{l})$ of enrichment cultures were examined by epifluoresence microscopy under green light excitation to determine the characteristics of phycoerythrin-containing cells.

Filtration for DNA and RNA. Surface (0 to $150 \mathrm{~m}$ ) seawater for vertical profiles was filtered for the extraction of DNA and RNA. Duplicate DNA (2 1) samples were filtered serially using a positive-pressure manifold driven by peristaltic pump, through $10 \mu \mathrm{m}$ pore size polyester (Poretics) and $0.2 \mu \mathrm{m}$ pore size Supor (Pall Gelman) filters, as has been done in previous studies of diazotroph diversity in marine waters (Church et al. 2005a,b). The filters were then placed immediately in cryovials containing $500 \mu \mathrm{l}$ TE buffer and flash frozen in liquid $\mathrm{N}_{2}$. For RNA collection, triplicate 11 samples were filtered using the same manifold through $0.2 \mu \mathrm{m}$ pore-size Supor (Pall Gelman) filters, placed in cryovials containing $100 \mu \mathrm{l}$ RNAse-free glass beads (BioSpec Products) and $350 \mu$ of buffer (RLT, Qiagen; containing $1 \%$ v/v $\beta$-mercaptoethanol), and flash frozen as described for DNA samples. For meso- to abyssopelagic samples (i.e. $>150 \mathrm{~m}$ ), 4.0 to 9.51 of seawater was serially filtered through $10 \mu \mathrm{m}$ pore-size, $47 \mathrm{~mm}$ diameter Nuclepore filters, then through $0.2 \mu \mathrm{m}$ pore-size Sterivex-GV capsule filters, which were capped and frozen at $-80^{\circ} \mathrm{C}$ prior to analysis. The samples were then transported in a liquid nitrogen dry shipper to the laboratory at the University of California Santa Cruz where they were processed for nucleic acid extraction.

DNA extraction. Surface water DNA samples were processed according to the protocols in Tillett \& Neilan (2000). Briefly, frozen DNA filters were thawed and then amended with $500 \mu$ l of xanthogenate extraction buffer (100 mM Tris, $20 \mathrm{mM}$ EDTA, 0.8M NaOAc, $1 \%$ SDS and $1 \%$ xanthogenate). The samples were incubated for $1.5 \mathrm{~h}$ at $70^{\circ} \mathrm{C}$ in a hybridization oven with agitation. The samples were vortexed and placed on ice for $30 \mathrm{~min}$. After filters were removed using flamesterilized forceps, the samples were centrifuged briefly at $5000 \times g$, and $750 \mu \mathrm{l}$ of isopropanol was added to the supernatant. The nucleic acids were precipitated for $10 \mathrm{~min}$ at room temperature, and tubes were centrifuged at $14000 \times g$ for $10 \mathrm{~min}$ to pellet nucleic acids. The supernatant was decanted, and $750 \mu$ of $70 \%$ EtOH was added to the pellet. The samples were then centrifuged at $14000 \times g$ for a further $10 \mathrm{~min}$, after which the supernatant was decanted. The pellets were air-dried overnight in a fume hood. The DNA pellet was resuspended in $30 \mu \mathrm{l}$ of deionized $\mathrm{H}_{2} \mathrm{O}$ and stored at $-20^{\circ} \mathrm{C}$ prior to analysis. Different extraction protocols were used for epipelagic and meso- to abyssopelagic samples because, in our experience, the xanthogenate protocol works well for smaller sample volumes; however, alternative methods (phenol: chloroform) provide less PCR inhibition for larger volumes. Thus, DNA samples from deeper water were processed using a phenol:chloroform protocol (Fuhrman et al. 1988), modified for Sterivex capsule filters (Hewson et al. 2006a,b). DNA was quantified using PicoGreen fluorescence (Molecular Probes) in an ABI 7500 real time PCR system (Applied Biosystems International).

RNA extraction. RNA was extracted from filters using the Qiagen RNeasy kit, following the protocol for bacteria supplied by the manufacturer, with the following modifications. Thawed filters were initially beadbeat in a BioSpec Products bead beater at a maximum setting for $6 \mathrm{~min}$, after which the tubes were centrifuged at $12000 \times g$ to pellet beads and filter materials. For Sterivex filters, beads and RLT buffer were first introduced into the luer lock end, and the filters were capped and bead beaten within the capsule assembly. The supernatant was then removed into a microcentrifuge tube (for Sterivexes, positive air pressure was used to push the eluent through the nipple end), prior to ethanol addition in the second step of the manufacturer's protocol. DNA was removed from RNA extracts using the Qiagen RNAse-free DNAse set and protocols in the RNEasy kit. RNA was quantified in final eluents using RiboGreen fluorescence (Molecular Probes) in an ABI 7500 real time PCR system.

Amplification of nifH and clone library preparation. Clone libraries were constructed by cloning nifH genes that were amplified using a nested, degenerate PCR amplification protocol (Zehr \& McReynolds 1989, Zani et al. 2000) (Table 2) and by cloning the amplification products using a commercial kit (pGEM-T Easy Vector II; Promega). Briefly, $4 \mu$ l of extracted DNA from 10 and $0.2 \mu \mathrm{m}$ filter samples (containing 0.08 to $0.34 \mathrm{ng}$ DNA in the $10 \mu \mathrm{m}$ size fraction and 2.46 to $11.7 \mathrm{ng}$ DNA in the $0.2 \mu \mathrm{m}$ size fraction) was amplified according to protocols in Zehr \& McReynolds (1989) and Church et al. (2005b) with the primers nifH1 to nifH4 (Table 3). The nifH genes in the deeper water samples were amplified using the same protocol; however,

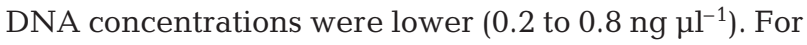
enrichment culture analysis, the Nuclepore filters with culture cells were cut into eighths, and one-eighth of the filter was placed in the PCR tube of the first PCR reaction round en lieu of extracted DNA (Kirchman 
Table 2. Summary of nifH amplification for samples collected in the North Atlantic (NA), equatorial Pacific and North Pacific Oceans. Eq Pac: Costa Rica Upwelling Dome; BATS: Bermuda Atlantic time series; Y: sample amplified with nested degenerate nifH primers; $\mathrm{N}$ : sample would not amplify

\begin{tabular}{|c|c|c|c|c|c|c|c|c|c|}
\hline \multirow{2}{*}{$\begin{array}{l}\text { Depth } \\
\text { (m) }\end{array}$} & \multirow{2}{*}{$\begin{array}{c}\text { BATS } \\
\mathrm{Y}\end{array}$} & \multicolumn{2}{|c|}{$\begin{array}{r}\text { Hydrostation S } \\
\text { HS6-05 HS9-05 }\end{array}$} & \multirow{2}{*}{$\frac{\mathrm{A} 22.36^{\mathrm{I}}}{\mathrm{N}}$} & \multirow{2}{*}{$\begin{array}{l}\text { NA } \\
\frac{\mathrm{A} 22.54}{\mathrm{~N}}\end{array}$} & \multirow{2}{*}{$\begin{array}{c}\text { Eq } \\
\text { Pac }\end{array}$} & \multirow[t]{2}{*}{$\begin{array}{c}\text { NE } \\
\text { Pacific }\end{array}$} & \multicolumn{2}{|c|}{$\begin{array}{l}\text { Kaena ALOHA } \\
\text { Point }\end{array}$} \\
\hline & & $\mathrm{N}$ & $\mathrm{Y}$ & & & & & & \\
\hline 25 & $\mathrm{Y}$ & & & & & & & & \\
\hline 40 & & $\mathrm{~N}$ & & & $\mathrm{~N}$ & & & & \\
\hline 60 & & $\mathrm{~N}$ & & & & & & & \\
\hline 75 & & & & $\mathrm{~N}$ & & & & & \\
\hline 80 & & $\mathrm{~N}$ & $\mathrm{~N}$ & & & & & & \\
\hline 95 & & $\mathrm{~N}$ & & & & & & & \\
\hline 100 & & & & & $\mathrm{~N}$ & & & & \\
\hline 125 & & & & $\mathrm{~N}$ & & & $\mathrm{Y}$ & & \\
\hline 140 & & $\mathrm{~N}$ & & & $\mathrm{Y}$ & & & & \\
\hline 160 & & $\mathrm{~N}$ & & & & & & & \\
\hline 200 & & & $\mathrm{Y}$ & & & & & & \\
\hline 250 & & & & & $\mathrm{~N}$ & & $\mathrm{Y}$ & & \\
\hline 275 & & & & $\mathrm{~N}$ & & & & & \\
\hline 505 & & & & & $\mathrm{Y}$ & & $\mathrm{Y}$ & $\mathrm{N}$ & $\mathrm{N}$ \\
\hline 575 & & & & $\mathrm{~N}$ & & & & & \\
\hline 750 & & & & & & & $\mathrm{Y}$ & & \\
\hline 950 & & & & $\mathrm{~N}$ & & & & & \\
\hline 1000 & & $\mathrm{Y}$ & & & $\mathrm{N}$ & & $\mathrm{N}$ & $\mathrm{Y}$ & $\mathrm{N}$ \\
\hline 1381 & & & & & & $\mathrm{Y}$ & & & \\
\hline 1500 & & & & & & & $\mathrm{~N}$ & & \\
\hline 2000 & & & & & & & & $\mathrm{~N}$ & $\mathrm{~N}$ \\
\hline 3125 & & & & $\mathrm{~N}$ & & & & & \\
\hline 4000 & & & & & & & & & $\mathrm{~N}$ \\
\hline 4875 & & & & $\mathrm{~N}$ & & & & & \\
\hline 5600 & & & & $\mathrm{~N}$ & & & & & \\
\hline 5948 & & & & $\mathrm{Y}$ & & & & & \\
\hline
\end{tabular}

et al. 2001). Then, $50 \mu \mathrm{l}$ reaction mixtures containing $1 \times \mathrm{PCR}$ buffer (Promega), $2.5 \mathrm{mM} \mathrm{MgCl} 2,1 \mu \mathrm{l}$ of a $10 \mathrm{mM}$ dNTP mix (Promega), $100 \mathrm{nmol}$ of each primer (nifH3 and nifH4),

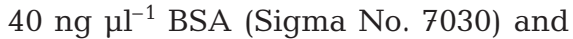
2.5 U Taq DNA polymerase (Promega) were subjected to the following thermal cycle program. The first step was a $3 \mathrm{~min}, 95^{\circ} \mathrm{C}$ denaturing step, followed by 25 cycles of denaturing at $95^{\circ} \mathrm{C}$ for $30 \mathrm{~s}$, annealing at $57^{\circ} \mathrm{C}$ for $30 \mathrm{~s}$ and extension at $72^{\circ} \mathrm{C}$ for $45 \mathrm{~s}$. Following all cycles there was a final extension step at $72^{\circ} \mathrm{C}$ for $7 \mathrm{~min}$. After the first round of amplification, $2 \mu \mathrm{l}$ of amplification product (ca. 560 bp) was then added to a second-round PCR reaction mix, identical to the first (except using the primers nifH1 and nifH2), and subjected to 30 PCR cycles as described previously (Zani et al. 2000, Zehr \& Turner 2001).

Second-round PCR amplification products were electrophoresed on a $1.2 \%$ agarose gel containing $1 \times$ SYBR Gold (Molecular Probes) for $1.2 \mathrm{~h}$ at $90 \mathrm{~V}$ and visualized in a GelDoc system (Bio-Rad Laboratories). Amplification products of approximately $365 \mathrm{bp}$ were excised using sterile razor blades

Table 3. Primers and probes used for analysis of nifH via PCR and qPCR. F: forward; R: reverse

\begin{tabular}{|c|c|c|c|}
\hline Primer name & Primer direction & Primer/Probe sequence $\left(5^{\prime}-3^{\prime}\right)$ & Source \\
\hline nifH1 & $\mathrm{F}$ & $\mathrm{TG}[\mathrm{T} / \mathrm{C}] \mathrm{GA}[\mathrm{T} / \mathrm{C}] \mathrm{CC}[\mathrm{A} / \mathrm{T} / \mathrm{G} / \mathrm{C}] \mathrm{AA}[\mathrm{A} / \mathrm{G}] \mathrm{GC}[\mathrm{A} / \mathrm{T} / \mathrm{G} / \mathrm{C}] \mathrm{GA}$ & Zehr \& McReynolds (1989) \\
\hline nifH2 & $\mathrm{R}$ & AN[A/G/T]GCCATCAT[T/C]TC[A/T/G/C]CC & Zehr \& McReynolds (1989) \\
\hline nifH3 & $\mathrm{F}$ & AT[A/G]TT[A/G]TT[A/T/G/C]GC[A/T/G/C]GC[A/G]TA & Zani et al. (2000) \\
\hline nifH4 & $\mathrm{R}$ & TT[T/C]TA[T/C]GG[A/T/G/C]AA[A/G]GG[A/T/G/C]GG & Zani et al. (2000) \\
\hline GroupA & $\begin{array}{l}\mathrm{F} \\
\mathrm{R} \\
\text { Probe }\end{array}$ & $\begin{array}{l}\text { AGCTATAACAACGTTTTATGCGTTGA } \\
\text { ACCACGACCAGCACATCCA } \\
\text { TCTGGTGGTCCTGAGCCTGGA }\end{array}$ & $\begin{array}{l}\text { Church et al. (2005a) } \\
\text { Church et al. (2005a) } \\
\text { Church et al. (2005a) }\end{array}$ \\
\hline Group B & $\begin{array}{c}\mathrm{F} \\
\mathrm{R} \\
\text { Probe }\end{array}$ & $\begin{array}{l}\text { TGGTCCTGAGCCTGGAGTTG } \\
\text { TCTTCTAGGAAGTTGATGGAGGTGT } \\
\text { TGTGCTGGTCGTGGTAT }\end{array}$ & $\begin{array}{l}\text { Church et al. (2005a) } \\
\text { Church et al. (2005a) } \\
\text { Church et al. (2005a) }\end{array}$ \\
\hline ВT5667A01 & $\begin{array}{c}\mathrm{F} \\
\mathrm{R} \\
\text { Probe }\end{array}$ & $\begin{array}{l}\text { TCGAGGACGTGATGAA } \\
\text { GTAGGACACATAGTCGA } \\
\text { TCATCACCRCGATCAACTTCCTTGA }\end{array}$ & $\begin{array}{l}- \\
- \\
-\end{array}$ \\
\hline BT19215A01 & $\begin{array}{c}\mathrm{F} \\
\mathrm{R} \\
\text { Probe }\end{array}$ & $\begin{array}{l}\text { ATCTGGAACTGGAAGA } \\
\text { TCTTCGAGGAAGTTGAT } \\
\text { AGTGTGTTGAGTCCGGTGGT }\end{array}$ & $\begin{array}{l}- \\
- \\
-\end{array}$ \\
\hline EP19212A01 & $\begin{array}{c}\mathrm{F} \\
\mathrm{R} \\
\text { Probe }\end{array}$ & $\begin{array}{l}\text { ACTGGAAGATGTACTGA } \\
\text { TCTTCGAGGAAGTCAAT } \\
\text { ATCAGGCGGTCCAGAGCCA }\end{array}$ & $\begin{array}{l}- \\
-\end{array}$ \\
\hline
\end{tabular}


and placed into sterile microcentrifuge tubes. DNA was extracted from gel slices using Zymoclean Gel DNA recovery kits (Zymo Research), and the DNA was cloned into pGEM-T Easy Vector II cloning kits (Promega) following the manufacturer's protocol. After clones were grown in liquid cultures $(600 \mu \mathrm{l})$ overnight in the presence of $8 \%$ glycerol, half of the culture was archived at $-80^{\circ} \mathrm{C}$, while the remainder was sent to the Interdisciplinary Center for Biotechnology Research (ICBR) at the University of Florida, Gainesville, for sequencing using Templiphi rolling circle amplification of plasmids in clone lysates followed by sequencing on a MegaBase capillary sequencer (Amersham).

RNA analysis followed the same protocol as DNA; however, it was preceded by a reverse transcriptase step to convert RNA into cDNA. The protocol consisted of reverse transcription of $7 \mu$ l of the extracted RNA (containing 0.25 to $0.5 \mathrm{ng}$ RNA) with $1 \mu \mathrm{l}$ of Superscript III Reverse Transcriptase (Invitrogen), $1 \mu$ l of RNAse OUT and 100 pmol each of the primers nifH2 and nifH4, with a $50 \mathrm{~min}$ incubation at $45^{\circ} \mathrm{C}$. cDNA $(2 \mu \mathrm{l})$ was added as template material in the PCR reactions.

Quantitative PCR of nifH phylotypes. Following identification of nifH phylotypes in the meso- to abyssopelagic samples, primer and probe sets were developed to target the following 3 clusters of phylotypes: BT5667A01 (product ca. 125 bp), BT19215A01 (130 bp) and EP19212A01 (product $90 \mathrm{bp}$; Table 3). Quantitative PCR was conducted on DNA extracts from samples from all deep water stations and on cDNA from the HS6-05/1000 m sample according to the protocol as follows. Briefly, $2 \mu \mathrm{l}$ of DNA extract was placed in duplicate $25 \mu \mathrm{l}$ qPCR reactions containing $1 \times$ Master Mix (ABI Taqman Universal PCR Master Mix), $400 \mathrm{nmol}$ of each primer and $200 \mathrm{nmol}$ of probe. Primer sequences are given in Table 3. The qPCR thermal cycling program consisted of a 10 min heating step at $60^{\circ} \mathrm{C}$, followed by a hot start at $95^{\circ} \mathrm{C}$ for $10 \mathrm{~min}$. After this initial treatment, the amplification cycling program consisted of $15 \mathrm{~s}$ at $95^{\circ} \mathrm{C}$, followed by annealing at $60^{\circ} \mathrm{C}$ for $1 \mathrm{~min}$ (annealing temperature for the probe BT5667A01 was $56^{\circ} \mathrm{C}$ ), after which fluorescence data were collected over 60 cycles. Dilution series (10-fold dilutions over 8 orders of magnitude) of plasmids containing the 3 mesopelagic nifH inserts were used for standards. Six negative controls with water added instead of template were also run in addition to the qPCR standards. The method for calculation of nifH quantity is outlined in Church et al. (2005a).

Oligonucleotide microarray analysis. The nifH 60mer oligonucleotide microarray consisted of $768 \mathrm{nifH}$ probes (Moisander et al. 2006), with each probe duplicated within each array slide. The microarray was constructed using the same slide chemistry as an earlier version of the array constructed with 96 probes and described in Moisander et al. (2006). Additionally, 6 control probes, repeated throughout the array, were included and used as positive and negative controls as described previously (Moisander et al. 2006). The microarray probes were 5'-modified with acrydite for signal amplification. Probes were included on the array that targeted sequences distributed in all the known clusters of the nifH phylogenetic tree (Zehr et al. 2003b). Based on prior tests of hybridization stringency under the conditions used, cross-hybridization at $>77 \%$ similarity was expected in microarray hybridizations. However, the specificity is most often much higher (Moisander et al. 2006).

Amplifications of nifH for microarray hybridizations were carried out following protocols for the clone libraries, with the exception that amplification for each sample was carried out in triplicate, to reduce PCR bias. After the first round of PCR, the replicates were combined, and this pooled product was used as a template in the second-round PCR reaction. PCR products from the second round were pooled and electrophoresed on a $1.2 \%$ TAE gel; the gel was purified (QiaQuick gel extraction kit, Qiagen), quantified and biotinylated using the Brightstar psoralen-biotin kit (Ambion) according to the manufacturer's protocols. In each biotinylation reaction, $10 \mu \mathrm{l}$ of PCR product at $5 \mathrm{ng}^{\mathrm{l}} \mathrm{l}^{-1}$ was used in $20 \mu \mathrm{l}$ of reaction volume, including $5 \mu \mathrm{l}$ of TE buffer and $5 \mu \mathrm{l}$ of positive control mix. Prior to hybridization, the biotinylated products were denatured at $96^{\circ} \mathrm{C}$ for $5 \mathrm{~min}$, then $13.2 \mu \mathrm{l}$ target was added to the hybridization buffer containing $2 \times \mathrm{SSPE}$, $1 \%$ SDS and $30 \%$ formamide in a $24 \mu \mathrm{l}$ final volume. The target was added to microarray slides that were covered with microarray cover slips and then hybridized at $50^{\circ} \mathrm{C}$ for $18 \mathrm{~h}$. After hybridization the slides were washed and subjected to secondary staining with the streptividin Alexa-555 stain (Molecular Probes), as previously described (Moisander et al. 2006). The slides were scanned using an Axon 4000B microarray scanner with $10 \mu \mathrm{m}$ pixel size. The detection threshold was determined, and the data were normalized using the positive controls, as previously described (Moisander et al. 2006).

Phylogenetic analysis. Sequence chromatograms were first consulted to resolve ambiguous bases, using the Chromas Lite chromatogram viewer (Technelysium). Sequences were transferred to BioEdit (Hall 1999). Sequences were searched against the nonredundant nucleotide GenBank database (NCBI, www.ncbi.nlm.nih.gov) using the online BLASTN function (Altschul et al. 1997). Closest matches in GenBank for each sequence or cluster of sequences were then imported into an ARB project file for each of the epipelagic and meso- to abyssopelagic sequence databases. Additionally, the full-length amplified nifH se- 
quence used originally to design the 10 strongest microarray hybridization signals was also included in each database for comparison. All sequences within each database were then aligned anchored to a PFAM (multiple sequence alignment of a protein family) alignment using HMMER (profile hidden Markov model software, www.sanger.ac.uk, or hmmer.wustl. edu) (Zehr et al. 2003b), and phylogenetic trees were constructed using neighbor-joining including bootstrap support of 1000 replicates. Phylogenetic trees were viewed using the Treeview program (Page 1996). The nifH sequences in this study have been deposited in GenBank under Accession Numbers DQ481241 to DQ481415.

Statistical analysis of microarray fingerprints. Analysis of microarray fingerprints was similar to that employed by other fingerprinting studies (e.g. TRFLP and ARISA) (Hewson \& Fuhrman 2006a). Microarray fingerprints were first normalized by expressing the fluorescence of each probe as a ratio of sample: mean control probe fluorescence. Duplicate microarray slides were then compared according to Hewson \& Fuhrman (2004). Briefly, only probes that fluoresced for both duplicate probes on replicate slides were considered for this analysis. The fluorescence is expressed as a percentage of total normalized fluorescence signal. A mean value of the percentage of normalized fluorescence signal was calculated for probes for each slide and further averaged for duplicate slides. The richness of each sample was calculated by enumerating the total number of probes detected.

Samples were compared by calculating the Whittaker Index $\left(S_{\mathrm{w}}\right)$ (Whittaker 1952) between each pair of microarray fingerprints, using:

$$
S_{\mathrm{w}}=1-\sum_{i=1}^{n} \frac{\left|b_{i 1}-b_{i 2}\right|}{2}
$$

where $b_{i 1}$ and $b_{i 2}$ are the percentage of total normalized fluorescence signal of the $i$ th probe in Microarrays 1 and 2, respectively. A matrix of pairwise Whittaker Indices was then converted into a dendrogram using the XLStat plugin (Addinsoft) in Microsoft Excel.

\section{RESULTS}

Surface water samples (0 to $100 \mathrm{~m}$ ) at BATS and Hydrostation $\mathrm{S}$ yielded nifH amplicons in only 3 of 9 samples, corresponding to 2 of 3 dates and only at the immediate surface (Table 3). In contrast, deeper samples yielded nifH amplicons at 200 and $1000 \mathrm{~m}$. Elsewhere in the Sargasso Sea, nifH was amplified from deeper water (>100 m) samples, but not from surface water. Finally, nifH was amplified from samples collected from meso- to bathypelagic water at most other locations.

\section{Sargasso Sea surface water nifH amplification and clone library analysis}

The nifH amplification using nested degenerate primers (Zehr \& McReynolds 1989, Zani et al. 2000) amplified multiple-sized products from surface water (0 to $100 \mathrm{~m}$ ) cast samples from HS6-05, including products around the expected size (ca. 360 bp). Because of concerns about potential primer degradation, PCR reactions were repeated twice using freshly synthesized primers each time, with the same results. Negative controls did not amplify in any PCR round; however, positive controls amplified and produced a single product. In addition, use of the general 16S rRNA primers 27F and 1392R (Lane 1991) yielded products of approximately $1370 \mathrm{bp}$ (data not shown). Sequencing of cloned nifH products yielded no nifH sequences (sequences were most similar to un-related and hypothetical protein products by TBLASTX searches), despite the extensive number of clones sequenced (341 clones). The unicellular cyanobacterial phylotypes A and B were not detected in DNA, nor expressed as gene transcripts using quantitative PCR, in the HS6-05 casts. Furthermore, nifH amplification was not detected in epipelagic samples from Stn A22.54 in November 2003. However, nitrogenase genes were amplified from surface waters at BATS in that same month and from a $5 \mathrm{~m}$ depth sample from HS9-05 (Table 3). After a $14 \mathrm{~d}$ incubation nifH was also amplified from all 6 enrichment cultures tested (1 each from the size fractions of $>10,10$ to 1 and 1 to $0.2 \mu \mathrm{m}$ in both $\mathrm{SO}$ and $\mathrm{SN}$ media) with water collected at Stn HS6-05. Epifluorescence microscope observation of enrichment cultures indicated the presence of coccoid phycoerythrin-containing cells, approximately $3 \mu \mathrm{m}$ in diameter, which were similar to cultures of Crocosphaera watsonii WH8501.

The nifH sequences obtained from Stn HS6-05 enrichment cultures (both SO and SN media) were consistently most similar to Crocosphaera watsonii $(\mathrm{n}=18$; Fig. 2). Sequences from HS9-05 at $5 \mathrm{~m}$ were either non-nifH (i.e. spurious products) or were similar to sequences obtained for enrichment cultures from HS605 (n $=3$, i.e. C. watsonii). The nifH sequences from the other two surface water libraries contained both cyanobacterial and proteobacterial phylotypes. At BATS, a $\gamma$-proteobacterial phylotype was detected that was most similar to sequences obtained near Hawaii (HT9025a11, AY706889).

Temperature and salinity profiles from Stns A22.36, A22.54 and HS6-05 are presented in Fig. 3. The water column was well stratified during sampling at Stn HS605. The autumn samples for Stns A22.36 and A22.54 showed a surface mixed layer of approximately 30 and 
Hydrostation S (HS)

BATS (BT)

\section{A22.54 (A5)}

Clone Library

Microarray

Enrichment Culture

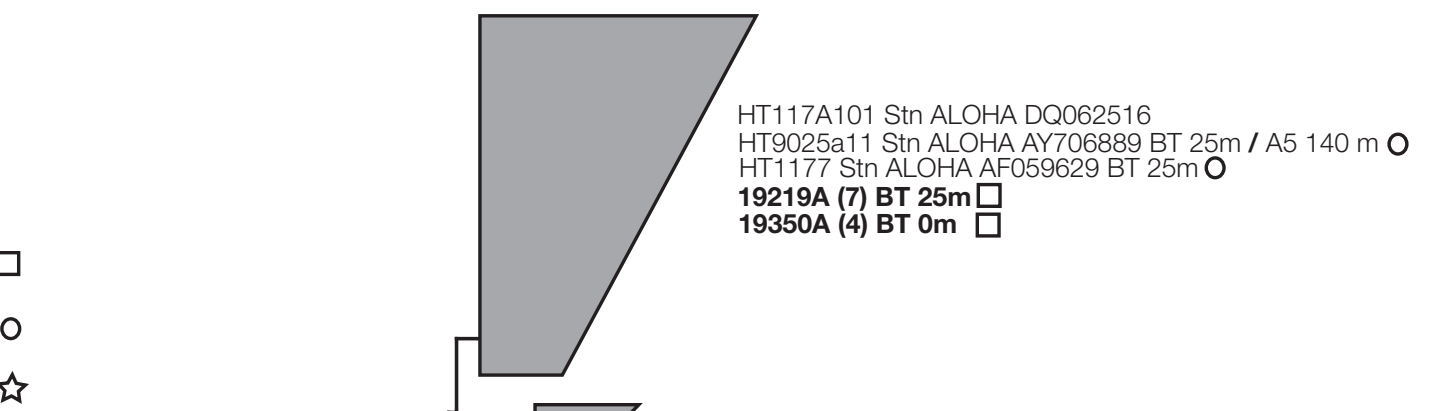

6 - Azomonas agilis AF216883 BT 25m O

89 Azomonas agilis AF216883 BT 25m O

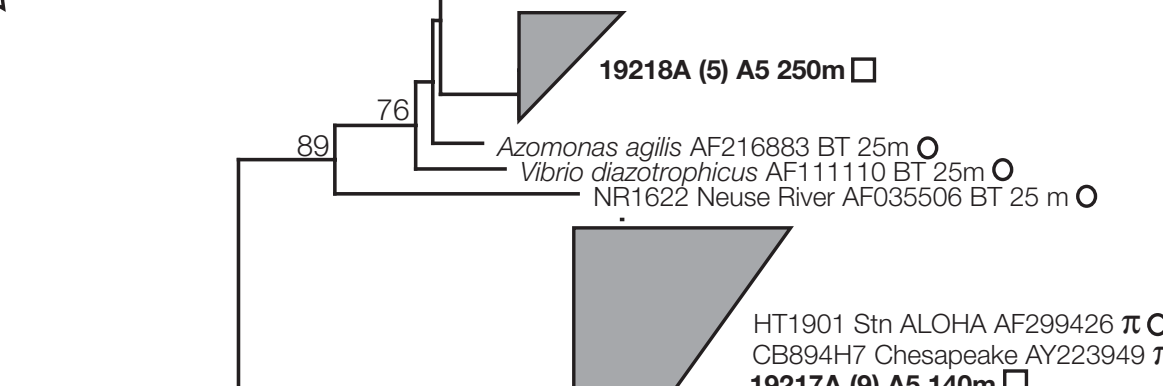

19217A (9) A5 140m $\square$

- Methylocysitis parvus AF484662 A5 140m O

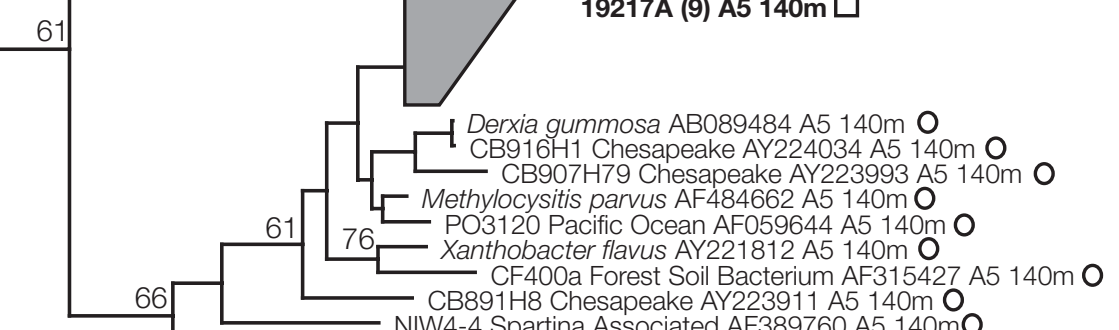

66 CB891H8 Chesapeake AY223911 A5 140m O NIW4-4 Spartina Associated AF389760 A5 140mO

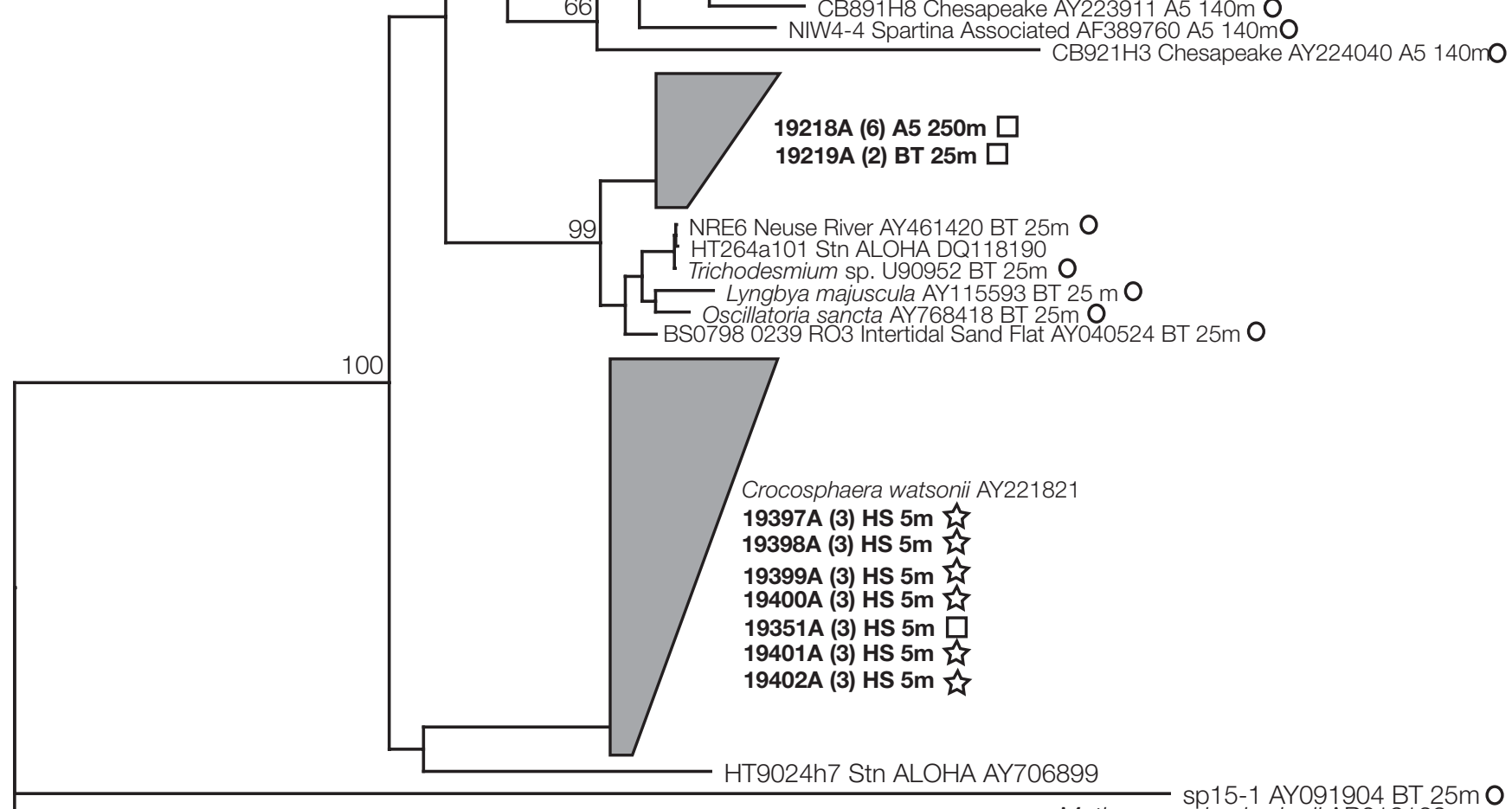

0.1

Fig. 2. Phylogenetic analysis of nifH sequences obtained from 0 to $250 \mathrm{~m}$ samples and enrichment cultures collected near Bermuda. The phylogenetic tree is based upon a PFAM (multiple sequence alignment of a protein family)-based HMMER (profile hidden Markov model software, www.sanger.ac.uk, or hmmer.wustl.edu) (Zehr et al. 2003b) alignment of sequences derived from nifH clone libraries, their nearest relatives in GenBank based upon BLAST searches, and probes that hybridized on the nifH microarray of amplicons. The number of sequences obtained within each cluster is given in parentheses. The tree was constructed using neighbor-joining of amino acid sequences, with 1000 replicate bootstrap supports. Only values $>50 \%$ are shown. Scale bar: 0.1 substitutions per site 


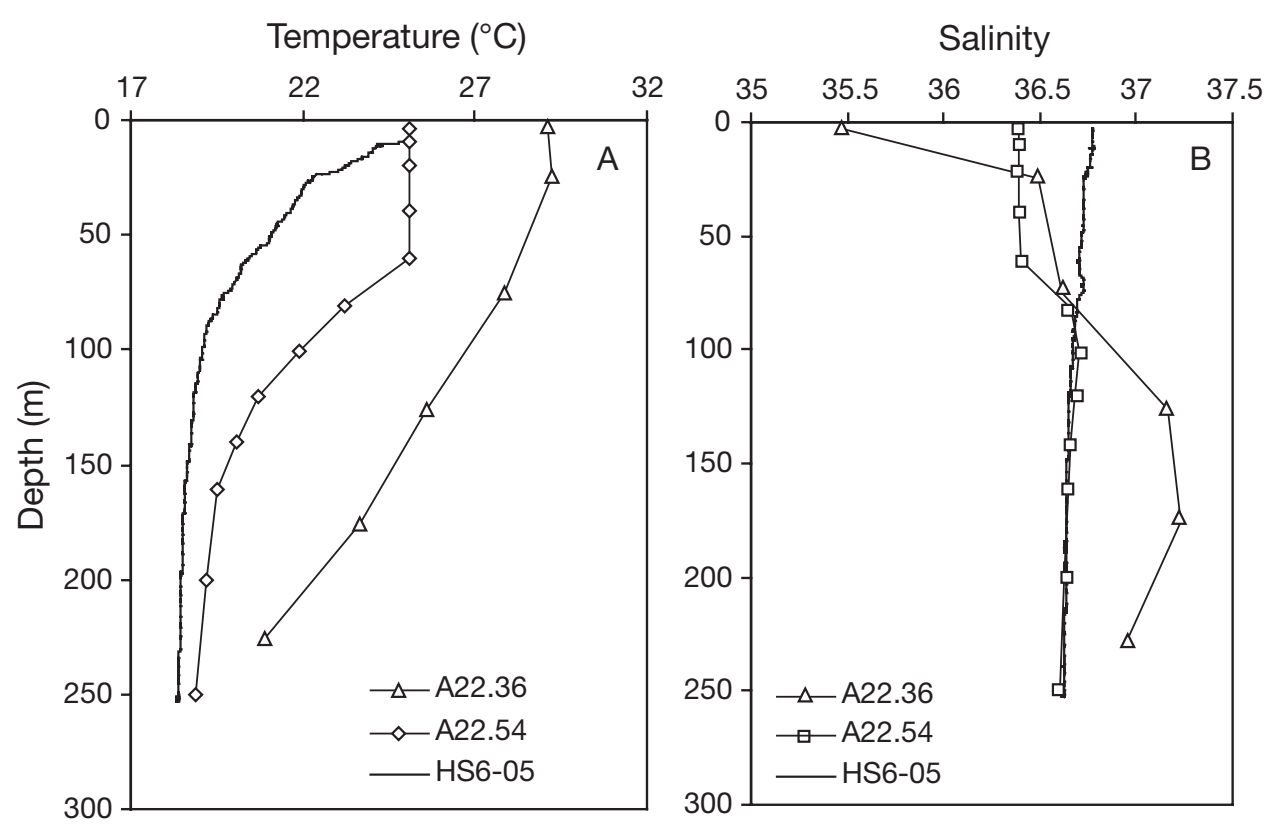

Fig. 3. Profiles of (A) temperature and (B) salinity at Hydrostation S (HS6-05), Stn A22.36 and Stn A22.54 at the time of sampling. Note the absence of a surface mixed layer during the HS6-05 sampling, which may have been a consequence of eddy activity

$60 \mathrm{~m}$, respectively. The deep chlorophyll maximum layer, identified from downcast CTD fluorometry, was at approximately $95 \mathrm{~m}$ at Stn HS6-05.

\section{Deep water nifH amplification and clone library analysis}

The nifH sequences were obtained from DNA samples collected at Stn HS6-05 at 1000 m, Stn HS9-05 at 200 m, Stn A22.36 at 5948 m and Stn A22.54 at 140 and $505 \mathrm{~m}$. RT-PCR amplification of a RNA sample from Stn HS6-06 at $1000 \mathrm{~m}$ also yielded nifH amplicons (Table 3). Sequences obtained from Stn A22.54 at $140 \mathrm{~m}(\mathrm{n}=9)$ and $505 \mathrm{~m}(\mathrm{n}=11)$ clustered with several $\beta$ - and $\alpha$-proteobacterial phylotypes. The nifH sequences generated from HS6-05/1000 m RNA and DNA samples $(\mathrm{n}=2)$ were identical and most similar to the nifH sequence from a $\beta$-Proteobacterium (Burkholderia vietnamensis AJ563286) and environmental forest soil nitrogenase sequences (AF415341 and AF315432; Fig. 4). Several Crocosphaera watsonii-like sequences were also recovered from Stn HS6-05 at $1000 \mathrm{~m}$.

All nifH genes were amplified from at least one depth within the meso- to abyssopelagic depths (i.e. $>150 \mathrm{~m}$ ) for all other stations sampled elsewhere, with the exception of Stn ALOHA. With the exclusion of samples from the NE Pacific at 250 to $500 \mathrm{~m}$ and Stn HS9-05 at 200 m, all sequences clustered strongly with proteobacterial phylotypes, forming several distinct clades (Fig. 2). Sequences obtained from the NE Pacific at 250 to $500 \mathrm{~m}$ included several cyanobacterial phylotypes. Sequences obtained from Stn A22.36 from $5948 \mathrm{~m}(\mathrm{n}=11)$ and from the equatorial Pacific at $1389 \mathrm{~m}(\mathrm{n}=16)$ formed separate clusters that were most closely related to each other and to phylotypes obtained from coastal sediments (e.g. AF016188). Sequences from the NE Pacific that were noncyanobacterial were similar to those obtained from the HS6-05/1000 m (n = 10) and A22.54/505 m (n = 11) sequences. All Kaena Point clone sequences $(\mathrm{n}=14)$ clustered strongly with those from Stn HS6-05 at $1000 \mathrm{~m}$ and the NE Pacific at $250 \mathrm{~m}$, and were closest to several sequences derived from methylotrophic bacteria (e.g. Xanthobacter flavus).

The quantitative PCR detected low abundances of 3 deep water phylotypes; none were detected in samples other than those from which the sequences were cloned. Phylotype BT5667A01 was present in the HS6$05 / 1000 \mathrm{~m}$ sample at 4.2 to 43.2 copies $\mathrm{l}^{-1}$, and gene transcripts were present at about the same concentration. BT19215A01 was detected at $<1$ to 2 copies $1^{-1}$ in the A22.36/5948 m sample; EP19212A01 was detected in the equatorial Pacific sample at the same concentration. Despite the similarity between the clones BT19212A01 and EP19215A01 in phylogenetic analysis, the primer/probe designed for each sequence did not amplify the standards from the reciprocal samples, suggesting high specificity. 
HS9-05 (H9)

HS6-05 (H6)

A22.36 (A3)

Equatorial Pacific (EP)

Kaena Point O'ahu (KP)

NE Pacific Shallow (NS)

NE Pacific Deep (ND)

Clone Library

Microarray
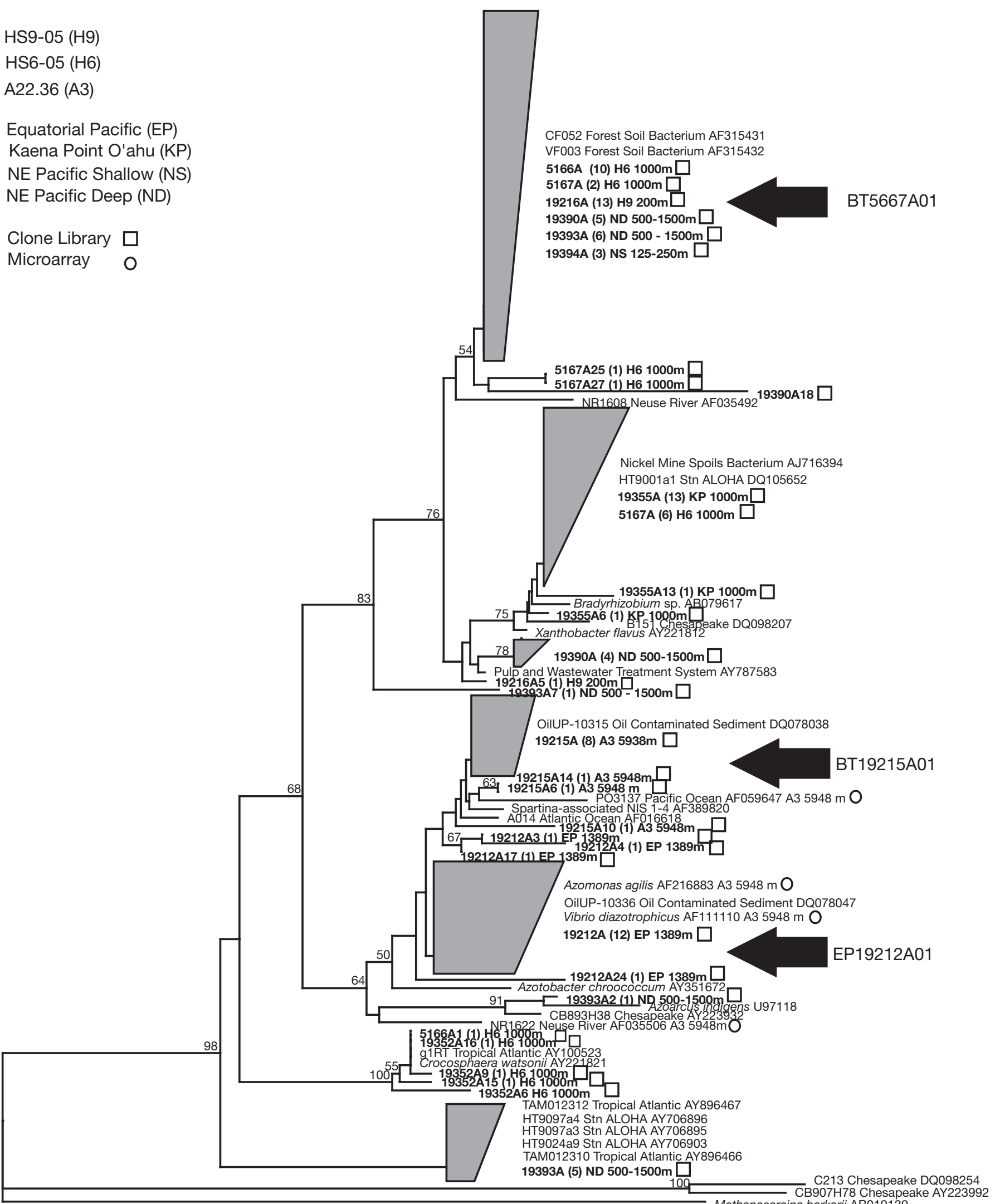


\section{Microarray analysis of nifH amplicons}

Microarrays hybridized to nifH amplicons prepared using nested, degenerate primers from the BATS/surface, BATS/25 m and HS9-05/5 m samples suggested samples had similar constituents to those observed using clone library analysis (Fig. 5). The strongest signal from all 3 samples came from a probe for a $\gamma$-proteobacterial sequence HT9025a11 (AY706889), which was up to 4 -fold greater than the next strongest signal (i.e. Trichodesmium thiebautii for BATS samples). Other strong signals at BATS included Lyngbya majuscula, a Group B unicellular cyanobacterial sequence, Oscillatoria sancta and Trichodesmium IMS101; at BATS/25 m, the probes with strong signals were the same as those that hybridized to amplicons from surface waters. Weaker signals in the BATS $/ 0 \mathrm{~m}$ sample were from several non-cyanobacterial nifH probes, including Klebsiella pneumoniae, Alcaligenes faecalis, Azotobacter vinelandii, Vibrio diazotrophicus, Magnetococcus and 1 cyanobacterial probe (Cyanothece sp.). In comparison, the strong signals from the BATS/25 m sample included Alcaligenes faecalis, Frankia sp., Azomonas agilis and Azotobacter vinelandii (nifH and vnfH).

Comparison between microarray fingerprints generated from 5 Sargasso Sea samples (the 4 noted above and Stn A22.36 at $5948 \mathrm{~m}$ ) demonstrated similarity between surface water diazotrophic assemblages at Stns BATS, HS9-05 and A22.36/25 m, but strong differences between euphotic $(<100 \mathrm{~m})$, sub-euphotic $(140 \mathrm{~m})$ and abyssopelagic $(5948 \mathrm{~m})$ assemblages (Fig. 6). The richest fingerprint was generated from the A22.54/140 m sample (95 probes detected), while those from the euphotic ( 34 to 50 probes detected) and abyssopelagic samples ( 47 probes detected) were less rich.

\section{DISCUSSION}

Our results demonstrate the genetic capability of bacterioplankton to fix nitrogen in the surface waters of the Sargasso Sea, but the abundance and diversity of diazotrophs varied in space and time. While low-diversity diazotrophic assemblages persist at some times in surface waters near Bermuda, we speculate that their abundances remain low until favorable conditions arise (e.g. during elevated water temperature, shorter day length, or establishment of a deeper mixed layer). Furthermore, our data demonstrate that diazotrophs were present in sub-euphotic waters in the Sargasso Sea and at almost all other stations sampled in the North Atlantic and Pacific. Finally, these results suggest that integrated water column nitrogen fixation in the Sargasso Sea and elsewhere may be underestimated if only illuminated surface waters are considered.

\section{Surface water diazotrophic assemblages}

The cultivation efforts in the Sargasso Sea yielded a phylotype most similar to Crocosphaera watsonii, a unicellular Group B cyanobacterium. This phylotype was evident in all size fractions of the enrichment cultures, including the 0.2 to $1 \mu \mathrm{m}$ fraction, which is smaller than its typical cell diameter ( 3 to $5 \mu \mathrm{m}$ ). The enrichments, in both $\mathrm{N}$-depleted (SO) and $\mathrm{N}$-replete (SN) media, in combination with the observation of only a single sequence similar to $C$. watsonii-like cyanobacteria in surface waters at Stn HS9-05 suggest that seed populations of these organisms were present in the plankton at Hydrostation S on 2 dates. These seed populations were present in extremely low numbers (a few cells per liter and almost undetectable using the current quantitative PCR approach). There are several possible reasons for this low abundance. We speculate that these cells are either advected from warmer waters closer to the Caribbean Sea or equatorial North Atlantic, where they have been observed previously (Falcon et al. 2002, Langlois et al. 2005), or may persist at low concentrations and become more abundant under favorable conditions. The conditions that may give rise to higher $C$. watsonii abundances include depleted inorganic $\mathrm{N}_{i}$ increased inorganic nutrients, e.g. Fe (dust inputs of Fe to the Sargasso Sea are greatest in late summer; Orcutt et al. 2001); increased surface water temperature; and a deeper thermocline, leading to a more stratified water column. We cannot discount the possibility that these results

Fig. 4. Phylogenetic analysis of nifH sequences from 200 to $5948 \mathrm{~m}$ in the Sargasso Sea and, for comparison, from 125 to $1389 \mathrm{~m}$ at stations elsewhere in the North Atlantic and Pacific Oceans (see Table 3). The $200 \mathrm{~m}$ sequences are included in this tree because of their similarity to $1000 \mathrm{~m}$ sequences at Hydrostation S. The phylogenetic tree is based upon a PFAM (multiple sequence alignment of a protein family)-based HMMER (profile hidden Markov model software, www.sanger.ac.uk, or hmmer.wustl.edu) (Zehr et al. 2003b) alignment of sequences, their nearest relatives in GenBank based upon BLAST searches, and probes that hybridized on the nifH microarray of amplicons. The number of sequences obtained within each cluster is given in parentheses. The tree was constructed using neighbor-joining of amino acid sequences, with 1000 replicate bootstrap supports. Only values $>50 \%$ are shown. Scale bar: 0.1 substitutions per site. The target sequences for design of qPCR primer and probe sets in the present study are indicated by the large arrows 

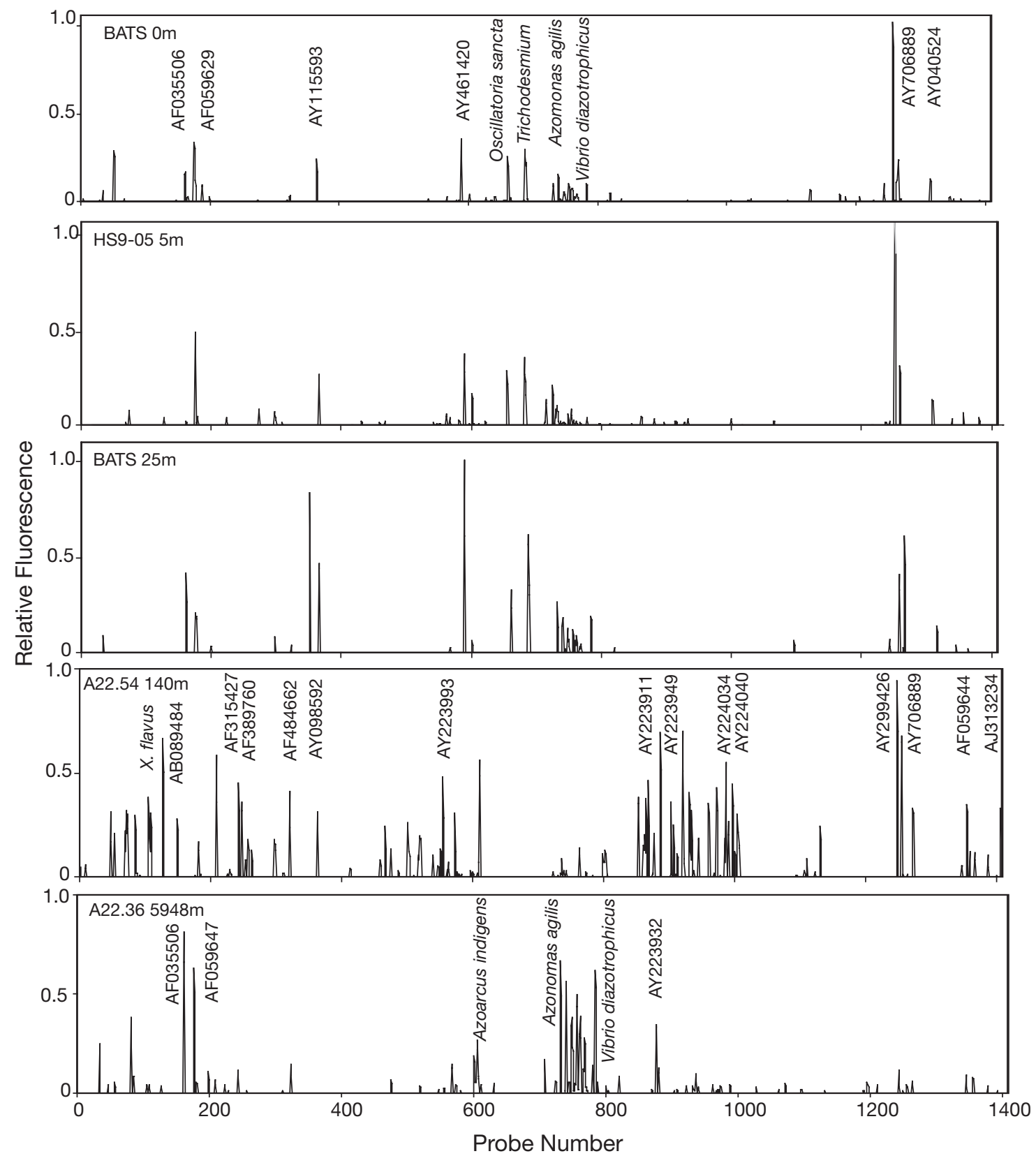

Fig. 5. Fingerprints of nifH microarray hybridizations; numbers on the $x$-axis indicate probe numbers, which are the same for the different fingerprints, and are duplicates of 710 different 23 mer oligonucleotide probes. The 10 most dominant components were identified for each fingerprint at the surface (0 to $25 \mathrm{~m}), 140$ and $5948 \mathrm{~m}$

were strongly affected by the association of a cyclonic eddy with Stn HS6-05. However, observation of only a single $C$. watsonii-like sequence in a library obtained from Stn HS9-05 (later in the season, when there was a more typical temperature and salinity profile) and lack of detection of nifH in surface waters in November 2003 at a station close to Hydrostation S (A22.54) suggest that their low abundance may be a common feature of this region during summer and early fall.
Using cultivation-independent approaches, the surface water diazotrophic assemblages appeared to have a low diversity based on nifH clone libraries and microarray hybridizations. Our results suggest that the diazotrophic assemblages at all sampling locations were less rich than at other locations, particularly Stn ALOHA in the North Pacific Ocean (Zehr et al. 2001) and within the Amazon River Plume in the North Atlantic Ocean (Falcon et al. 2002, 2004), but similar to 
Hydro S 5m

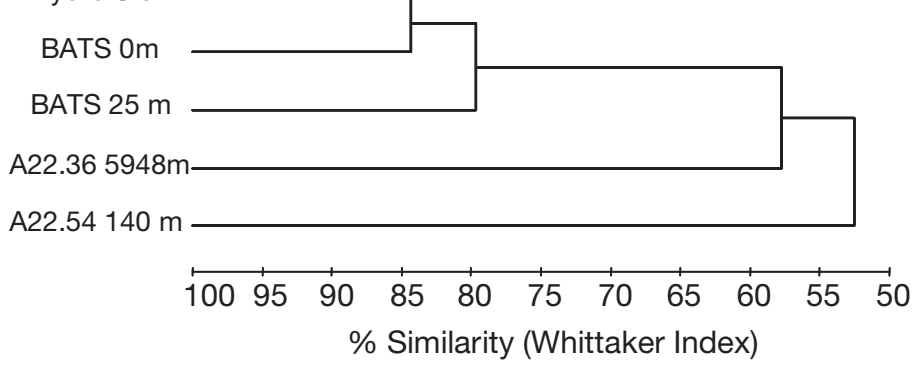

Fig. 6. Similarity between diazotrophic assemblages hybridized on the nifH DNA microarray. The tree is based upon the Whittaker Index (Whittaker 1952) and was constructed using the unweighted pair-group mean analysis (Sokal \& Rohlf 1995)

the diversity at other stations reported for the equatorial and eastern Atlantic (Langlois et al. 2005). The large numbers of identical sequences in small clone libraries indicate dominance of the assemblage by a few different phylotypes, a result which is congruent with studies of bacterioplankton diversity (Schwalbach et al. 2004). This is further emphasized by the dominance of the hybridization signal of only a handful of phylotypes on microarrays hybridized to surface water nifH amplification products and by the low total numbers of microarray probes that hybridized to amplification products from surface water samples.

Sequences obtained from surface and $25 \mathrm{~m}$ depth waters at Stn BATS showed similar phylotypes and were consistent with microarray hybridization results. All BATS clones were $>99 \%$ similar at the nucleotide level to sequence HT9025a11 (AY706889) from the Pacific Ocean. This result is consistent with microarray analysis of the same sample, where this sequence had a nearly 4-fold higher signal intensity than any other probe. The HT9025a11 phylotype was observed during a study of nifH expression at Stn ALOHA near Hawaii, and investigations of diel expression cycles revealed it was homogeneously distributed in the upper $100 \mathrm{~m}$, apparently with statistically indistinguishable expression over $60 \mathrm{~h}$ of sampling (Church et al. 2005b). The observation of a phylotype similar to that reported previously in the North Pacific Ocean suggests that there are non-cyanobacterial diazotrophic phylotypes widely distributed in the oligotrophic surface ocean.

The Sargasso Sea has lower concentrations of P than those found at Stn ALOHA (Cavender-Bares et al. 2001). While the ratio of $\mathrm{N}: \mathrm{P}$ in surface waters at Stn BATS was lower than the Redfield ratio of 16:1 year-round, it was only lower than 16:1 during stratified periods (Cavender-Bares et al. 2001). This observation was consistent with lower calculated $\mathrm{N}^{*}$ values at Stn BATS on the $18^{\circ} \mathrm{C}$ isotherm compared to values at Stn ALOHA (Gruber \& Sarmiento 1997). These studies suggest that nitrogen fixation is not important at Stn BATS. In contrast, a recent modeling effort suggested that nitrogen fixation by Trichodesmium was insufficient to maintain the phytoplankton abundances observed in remote sensing surveys at Stn BATS (Coles \& Hood 2004). Our results also indicate that physico-chemical conditions may not always favor, or select for, diazotrophs in this region. The factors causing lower diazotrophic diversity in Sargasso Sea waters compared to other studies at Stn ALOHA and at other locations are unknown. However, it is likely that less favorable conditions, resulting in lower abundances of diazotrophs may result in less diverse assemblages.

\section{Meso- to abyssopelagic diazotrophic assemblages}

In addition to surface water observations, our results demonstrate that diazotrophs are present in the mesoto abyssopelagic $(>100 \mathrm{~m})$ waters of the Sargasso Sea. The 2 clone libraries constructed from deeper samples in the North Atlantic (Stn A22.54 at 140 and $250 \mathrm{~m}$ ) demonstrated the presence of predominantly proteobacterial diazotrophs; however, several Trichodesmium thiebautii sequences were also recovered from the $250 \mathrm{~m}$ sample and several Crocosphaera watsonii-like sequences were recovered from the HS605/1000 m sample. This was unexpected since the euphotic zone extends to only about $150 \mathrm{~m}$, and these cyanobacteria typically have maximal abundances in surface waters (Orcutt et al. 2001). It is conceivable that the presence of cyanobacterial gene sequences at depth are the result of sinking material, either as copepod fecal pellets (O'Neil \& Roman 1994) or attached to aggregates, which is consistent with recent reports of Prochlorococcus genes at $700 \mathrm{~m}$ (DeLong et al. 2006). The nifH sequence phylotypes from the deeper samples at Stn A22.54 clustered with proteobacterial diazotrophs; however, the sequences from different depths were not similar to each other and had low similarity $(<96 \%)$ with nifH sequences in GenBank. Microarray analysis of the A22.54/140 m sample was in agreement with cloned sequences, with a greater number of probes having a positive signal at this depth relative to surface or abyssopelagic waters. This is consistent with previous observations of more diverse diazotrophic assemblages in waters immediately below the deep chlorophyll maximum layer based upon a TRFLP fingerprinting approach (Hewson \& Fuhrman 2006c).

The phylotype observed in nifH clone libraries from Stn HS6-05 at $1000 \mathrm{~m}$ clustered most closely with putative PCR contaminant $\beta$-proteobacterial nifH sequences and terrestrial soil bacteria (Zehr et al. 
2003a). To confirm the presence of these genes in the extracted DNA and RNA (and to eliminate the possibility of PCR or RT-PCR contamination), qPCR was conducted on DNA extracts from a vertical profile at Stn HS6-05 using phylotype-specific primer/probe sets. No amplification was detected in shallower samples at the same location, yet amplification was detected in gene transcripts from the same depth and time. In addition, multiple negative controls in the qPCR reaction failed to amplify. This phylotype was still detectable (albeit at low concentrations) at Stn HS9-05 at $200 \mathrm{~m} 3$ mo later. These results suggest that the phylotype is not a reagent contaminant.

Cloning and sequencing of nifH from other locations (Stn A22.36 at $5948 \mathrm{~m}$, the NE Pacific, the equatorial Pacific and Kaena Point) demonstrated a wider dispersal of the phylotype, similar to the putative PCR contaminant, detected in the mesopelagic zone of Stn HS6-05. Abyssopelagic sequences generated from samples at Stn A22.36 at $5948 \mathrm{~m}$ formed closely related clusters with mesopelagic sequences from the equatorial Pacific (1389 m). However, when the primer/probe sets designed for sequences derived from one location were applied to the other locations, the sequence types were not detected by qPCR. These data indicate that some phylotypes of bacteria in the deep ocean are site specific and present in low abundance, which is consistent with reports of high spatial variability between mesopelagic and bathypelagic bacterioplankton assemblages (Hewson et al. 2006b).

Another cluster of sequences, closest to methanotrophic Xanthobacter flavus, was detected at Stn HS605, and additionally at Kaena Point and in the NE Pacific Ocean. This information suggests that the groups may be widely distributed between locations in different ocean basins. However, we cannot exclude the possibility that this phylotype represents a PCR contaminant, since we have no supporting data on abundance by qPCR or amplification from gene transcripts.

The phylogeny of nitrogen fixers has been previously examined in only a handful of bathypelagic samples, including a single 22001 sample (2000 m depth) from near the Juan de Fuca Ridge, as part of a broader investigation of diazotroph phylogeny in hydrothermal vent fluids (Mehta et al. 2003), and 2 samples (2200 and $2400 \mathrm{~m}$ ) from the NE Pacific along the Juan de Fuca Ridge (Mehta et al. 2005). The first study found very low diversity ( 2 clusters of very closely related phylotypes) of diazotrophs in the sample resulting in Cluster II nifH sequences closest to Archaea and alternative nitrogenases and primarily Cluster III sequences from another sample. The second study (Mehta et al. 2005) found mostly Cluster II archaeal nifH genes, with almost no bacterial sequences.
The detection of nifH genes in deep waters near the Juan de Fuca Ridge is consistent with our findings of diazotrophs in the meso- to abyssopelagic regions of several stations in the Sargasso Sea. In contrast to previous studies, however, we did not detect archaeal nifH sequences at any location. One possible explanation for this discrepancy may arise from the utilization of different primer sets for the amplification of the nitrogenase genes. Primer biases in PCR amplification have been well documented for other genes, e.g. 16S rRNA, and may arise due to kinetic differences between primer and target sequences (Suzuki et al. 1998).

Our results highlight the importance of using a combined cultivation-dependent and cultivationindependent approach to observe functional groups of bacteria in the ocean. We observed Crocosphaera watsonii-like sequences in enrichment cultures, and yet did not observe them in the matching water column samples from which the enrichments originated. This implies a detection threshold for our PCR-based analyses (nifH PCR and qPCR). Use of a combined approach has, in this case, elucidated the presence of cultivatable low-abundance phylotypes which may escape detection if only PCR-based approaches are used. Conversely, reliance on cultivation-based approaches to observe diazotrophs would likely not detect the vast majority of as yet uncultivated phylotypes detected in this study, particularly those in deeper waters.

\section{CONCLUSIONS}

Our results indicate that diazotrophs were not abundant in the Sargasso Sea near Bermuda on the sampling dates of this study, even though unicellular cyanobacteria could be cultivated from the samples. These results suggest that diazotrophic cyanobacteria may have low-abundance seed populations that can respond to favorable conditions for growth. The fundamental factors that lead to their growth are unresolved, but are likely to be temperature and availability of nutrients ( $\mathrm{N}, \mathrm{P}$ and Fe). Diazotrophic assemblages in surface waters were not as diverse as those reported in the North Pacific Ocean (Zehr et al. 1998, 2000, 2001), and were dominated by non-cyanobacterial nifH phylotypes. Intriguingly, proteobacterial nitrogenase genes were detected in the mesopelagic of the Sargasso Sea and the Pacific Ocean. At least some of these genes were expressed, indicating that some low-level nitrogen fixation may occur in the deep ocean. This may indicate that studies of integrated water column nitrogen fixation may be underestimates, since deepwater diazotrophic nitrogenase activity, integrated over several thousand meters, could contribute sub- 
stantially to the production of new N. Further research is necessary to evaluate the evolutionary and ecological significance of bacterial nitrogen fixation in the deep waters of the oceans.

Acknowledgements. The authors acknowledge the assistance of R. Nguyen and N. Strauli for laboratory work; R. Foster for collection of the sample from the NE Pacific; K. Johnson for provision of valuable ship time for R. Foster; D. M. Karl, C. Mahaffey, T. Gregory and R. Poretsky for assistance in sample collection in Hawaii and provision of ship time; and the crews of the RV 'Weatherbird II', RV 'Western Flyer', RV 'Kilo Moana' and staff of the Bermuda Biological Station for Research. This work was supported by a Gordon and Betty Moore Foundation grant in marine microbiology, NSF Grants OCE0425363 and OCE0131762 awarded to J.P.Z., and NSF Grants OCE0241614 and MCB0237728 awarded to C.A.C.

\section{LITERATURE CITED}

Altschul SF, Madden TL, Schaffer AA, Zhang J, Zhang Z, Miller W, Lipman DJ (1997) Gapped BLAST and PSIBLAST: a new generation of protein database search programs. Nucleic Acids Res 25:3389-3402

Bird C, Martinez JM, O'Donnell AG, Wyman M (2005) Spatial distribution and transcriptional activity of an uncultured clade of planktonic diazotrophic gamma-proteobacteria in the Arabian Sea. Appl Environ Microbiol 71:2079-2085

Braun ST, Proctor LM, Zani S, Mellon MT, Zehr JP (1999) Molecular evidence for zooplankton-associated nitrogen fixing anaerobes based upon amplification of the nifH gene. FEMS Microbiol Ecol 28:273-279

Capone DG (1993) Determination of nitrogenase activity in aquatic samples using the acetylene reduction procedure. In: Kemp PF, Sherr BF, Sherr EB, Cole JJ (eds) Handbook of methods in aquatic microbial ecology, Vol 1. Lewis Press, Boca Raton, FL, p 621-631

Capone DG, Zehr JP, Paerl HW, Bergman B, Carpenter EJ (1997) Trichodesmium, a globally significant marine cyanobacterium. Science 276:1221-1229

Carpenter EJ, Romans K (1991) Major role of the cyanobacterium Trichodesmium in nutrient cycling in the North Atlantic Ocean. Science 254:1356-1358

Carpenter EJ, Montoya JP, Burns J, Mulholland MR, Subramaniam A, Capone DG (1999) Extensive bloom of a $\mathrm{N}_{2}$ fixing diatom/cyanobacterial association in the tropical Atlantic Ocean. Mar Ecol Prog Ser 185:273-283

Cavender-Bares KK, Karl DM, Chisholm SW (2001) Nutrient gradients in the western North Atlantic Ocean: relationship to microbial community structure and comparison to patterns in the Pacific Ocean. Deep-Sea Res I 48: 2373-2395

Church MJ, Jenkins BD, Karl DM, Zehr JP (2005a) Vertical distributions of nitrogen-fixing phylotypes at Stn ALOHA in the oligotrophic North Pacific Ocean. Aquat Microb Ecol 38:3-14

Church MJ, Short CM, Jenkins BD, Karl DM, Zehr JP (2005b) Temporal patterns of nitrogenase gene (nifH) expression in the oligotrophic North Pacific Ocean. Appl Environ Microbiol 71:5362-5370

Coles VJ, Hood RR (2004) Modeling the impact of Trichodesmium and nitrogen fixation in the Atlantic Ocean. J Geophys Res 109:C06007
DeLong EF, Preston CM, Mincer T, Rich V and 8 others (2006) Community genomics among stratified microbial assemblages in the ocean's interior. Science 311:496-503

Falcon LI, Cipriano F, Christoserdov AY, Carpenter EJ (2002) Diversity of diazotrophic unicellular cyanobacteria in the tropical North Atlantic Ocean. Appl Environ Microbiol 68: 5760-5764

Falcon LI, Carpenter EJC, Cipriano F, Bergman B, Capone DG (2004) $\mathrm{N}_{2}$ fixation by unicellular bacterioplankton from the Atlantic and Pacific Oceans: phylogeny and in situ rates. Appl Environ Microbiol 70:765-770

Fasham MJR, Balino BM, Bowles MC, Anderson R and 45 others (2001) A new vision of ocean biogeochemistry after a decade of the Joint Global Ocean Flux Study (JGOFS). Ambio Spec Issue 10:4-31

Foster RA, Bergman B, Carpenter EJ (2006) Unicellular cyanobionts in open ocean dinoflagellates, radiolarians, and tintinids: ultrastructural characterization and immuno-localization of phycoerythrin and nitrogenase. J Phycol 42:453-463

Fuhrman JA, Comeau DE, Hagström A, Chan AM (1988) Extraction of DNA suitable for molecular biological studies from natural planktonic microorganisms. Appl Environ Microbiol 54:1426-1429

Gruber N, Sarmiento J (1997) Global patterns of marine nitrogen fixation and denitrification. Global Biogeochem Cycles 11:235-266

Hall TA (1999) BioEdit: a user-friendly biological sequence alignment editor and analysis program for Windows 95/98/NT. Nucleic Acids Symp Ser 41:95-98

Hewson I, Fuhrman JA (2004) Bacterioplankton species richness and diversity along an estuarine gradient in Moreton Bay, Australia. Appl Environ Microbiol 70:3425-3433

Hewson I, Fuhrman JA (2006a) Improved strategy for comparing microbial assemblage fingerprints. Microb Ecol DOI: $10.1007 / \mathrm{s} 00248-005-0144-9$

Hewson I, Fuhrman JA (2006b) Spatial and vertical biogeography of coral reef sediment bacterial and diazotroph communities. Mar Ecol Prog Ser 306:79-86

Hewson I, Fuhrman JA (2006c) Viral impacts upon marine bacterioplankton assemblage composition. J Mar Biol Assoc UK 86:577-589

Hewson I, Capone DG, Steele JA, Fuhrman JA (2006a) Influence of the Amazon and Orinoco offshore surface water plumes on oligotrophic bacterioplankton diversity in the West Tropical Atlantic. Aquat Microb Ecol 43: 11-22

Hewson I, Steele JA, Capone DG, Fuhrman JA (2006b) Remarkable heterogeneity in meso- to bathypelagic bacterioplankton assemblage composition. Limnol Oceanogr 51:1274-1283

Johnston AWB, Li Y, Ogilvie L (2005) Metagenomic marine nitrogen fixation-Feast or famine? Trends Microbiol 13: 416-420

Kirchman DL, Yu L, Fuchs BM, Amann R (2001) Structure of bacterial communities in aquatic systems as revealed by filter PCR. Aquat Microb Ecol 26:13-22

Lane (1991) 16S/23S sequencing. In: Stackebrandt E, Goodfellow $M$ (eds) Nucleic acid techniques in bacterial systematic. Chichester, Wiley, p115-175

Langlois RJ, LaRoche J, Raab PA (2005) Diazotrophic diversity and distribution in the tropical and subtropical Atlantic Ocean. Appl Environ Microbiol 71:7910-7919

Mehta MP, Butterfield DA, Baross JA (2003) Phylogenetic diversity of nitrogenase (nifH) genes in deep-sea and hydrothermal vent environments of the Juan de Fuca ridge. Appl Environ Microbiol 69:960-970 
Mehta MP, Huber JA, Baross JA (2005) Incidence of novel and potentially archaeal nitrogenase genes in the deep Northeast Pacific Ocean. Environ Microbiol 7:1525-1534

Moisander PH, Shiue L, Steward GF, Jenkins BD, Bebout BM, Zehr JP (2006) Application of a nifH oligonucleotide microarray for profiling diversity of $\mathrm{N}_{2}$-fixing microorganisms in marine microbial mats. Environ Microbiol 8:1721-1735

Montoya JP, Carpenter EJ, Capone DG (2002) Nitrogen fixation and nitrogen isotope abundances in zooplankton of the oligotrophic North Atlantic. Limnol Oceanogr 47: $1617-1628$

Montoya JP, Holl CM, Zehr JP, Hansen A, Villareal TA, Capone DG (2004) High rates of $\mathrm{N}_{2}$ fixation by unicellular diazotrophs in the oligotrophic Pacific Ocean. Nature 430: 1027-1031

Morris RM, Vergin KL, Cho JC, Rappe M, Carlson CA, Giovannoni SJ (2005) Temporal and spatial response of bacterioplankton lineages to annual convective overturn at the Bermuda Atlantic time-series study site. Limnol Oceanogr 50:1687-1696

O'Neil JM, Roman MR (1994) Ingestion of the cyanobacterium Trichodesmium spp. by pelagic harpacticoid copepods Macrosetella, Miracia and Oculosetella. Hydrobiologia 292/293:235-240

Orcutt KM, Lipschultz F, Gundersen K, Arimoto R, Michaels AF, Knap AH, Gallon JR (2001) A seasonal study of the significance of $\mathrm{N}_{2}$ fixation by Trichodesmium spp. at the Bermuda Atlantic time-series study (BATS) site. Deep-Sea Res II 48:1583-1608

Page R (1996) TreeView: an application to display phylogenetic trees on personal computers. Comput Appl Biosci 12:357-358

Proctor LM (1997) Nitrogen-fixing, photosynthetic, anaerobic bacteria associated with pelagic copepods. Aquat Microb Ecol 12:105-113

Schwalbach MS, Hewson I, Fuhrman JA (2004) Viral effects on bacterial community composition in marine plankton microcosms. Aquat Microb Ecol 34:117-127

Short SM, Jenkins BD, Zehr JP (2004) Spatial and temporal distribution of two diazotrophic bacteria in the Chesapeake Bay. Appl Environ Microbiol 70:2186-2192

Sokal RR, Rohlf FJ (1995) Biometry. The principles and practice of statistics in biological research, Vol 3. Freeman, New York

Steinberg DK, Carlson CA, Bates NR, Johnson RJ, Michaels AF, Knap AH (2001) Overview of the US JGOFS Bermuda Atlantic time-series study (BATS): a decade-scale look at ocean biology and biogeochemistry. Deep-Sea Res II 48: 1405-1447

Suzuki MT, Rappé M, Giovannoni SJ (1998) Kinetic bias in estimates of picoplankton community structure obtained

Editorial responsibility: William Li,

Dartmouth, Nova Scotia, Canada by measurements of small-subunit rRNA gene PCR amplicon length heterogeneity. Appl Environ Microbiol 64: $4522-4529$

Sweeney EN, McGillicuddy DJ, Buesseler KO (2003) Biogeochemical impacts due to mesoscale eddy activity in the Sargasso Sea as measured at the Bermuda Atlantic time series study (BATS). Deep-Sea Res II 50:3017-3039

Tillett D, Neilan B (2000) Xanthogenate nucleic acid isolation from cultured and environmental cyanobacteria. J Phycol 36:251-258

Venter JC, Remington K, Heidelberg JF, Halpern AL and 19 others (2004) Environmental genome shotgun sequencing of the Sargasso Sea. Science 304:66-74

Waterbury JB, Watson SW, Valois FW, Franks DG (1986) Biological and ecological characterisation of the marine unicellular cyanobacterium Synechococcus. Can Bull Fish Aquat Sci 214:71-120

Westberry TK, Siegel DA (2003) Phytoplankton natural fluorescence variability in the Sargasso Sea. Deep-Sea Res I 50:417-434

Whittaker RH (1952) A study of summer foliage insect communities in the Great Smoky Mountains. Ecol Monogr 22: $1-44$

Zani S, Mellon MT, Collier JL, Zehr JP (2000) Expression of nifH genes in natural microbial assemblages in Lake George, New York, detected by reverse transcriptase PCR. Appl Environ Microbiol 66:3119-3124

Zehr JP, McReynolds LA (1989) Use of degenerate oligonucleotides for amplification of the nifH gene from the marine cyanobacterium Trichodesmium thiebautii. Appl Environ Microbiol 55:2522-2526

Zehr JP, Turner PJ (2001) Nitrogen fixation: nitrogenase genes and gene expression. Methods Microbiol 30: 271-286

Zehr JP, Mellon MT, Zani S (1998) New nitrogen-fixing microorganisms detected in oligotrophic oceans by the amplification of nitrogenase (nifH) genes. Appl Environ Microbiol 64:3444-3450

Zehr JP, Carpenter EJ, Villareal TA (2000) New perspectives on nitrogen-fixing microorganisms in tropical and subtropical oceans. Trends Microbiol 8:68-73

Zehr JP, Waterbury JB, Turner PJ, Montoya JP, Omoregie E, Steward G, Hansen A, Karl DM (2001) Unicellular cyanobacteria fix $\mathrm{N}_{2}$ in the subtropical North Pacific Ocean. Nature 412:635-638

Zehr JP, Crumbliss LL, Church MJ, Omoregie E, Jenkins BD (2003a) Nitrogenase genes in PCR and RT-PCR reagents: implications for studies of diversity of functional genes. Biotechniques 35:996-1005

Zehr JP, Jenkins BD, Short SM, Steward G (2003b) Nitrogenase gene diversity and microbial community structure: a cross-system comparison. Environ Microbiol 5:539-554

Submitted: August 11, 2006; Accepted: October 31, 2006

Proofs received from author(s): January 11, 2007 